Tropical Journal of Pharmaceutical Research May 2019; 18 (5): 1033-1039

ISSN: $1596-5996$ (print); 1596-9827 (electronic)

(C) Pharmacotherapy Group, Faculty of Pharmacy, University of Benin, Benin City, 300001 Nigeria.

Available online at http://www.tjpr.org

Original Research Article

http://dx.doi.org/10.4314/tjpr.v18i5.17

\title{
Lidocaine, an anesthetic drug, protects Neuro2A cells against cadmium toxicity
}

\author{
Peng Chen, Wenyu Zhang, Xuefeng Li, Longyun $\mathrm{Li}^{*}$ \\ Department of Anesthesiology, China-Japan Union Hospital of Jilin University, Changchun 130033, Jilin, China \\ ${ }^{*}$ For correspondence: Email: VMaciveragook@yahoo.com; Tel/Fax: 0086--0431-84997222
}

Sent for review: 2 November 2018

Revised accepted: 18 April 2019

\begin{abstract}
Purpose: To investigate the neuroprotective effect of lidocaine in Neuro2A cells Methods: Differentiated N2a cells were used in this study. Cell viability and neuroprotection were assessed using dimethylthiazol-2-yl)-2,5-diphenyltetrazolium bromide (MTT) and trypan blue assays, while Bax/Bcl-2 expression was assayed by western blotting. Mitochondrial membrane potential, reactive oxygen species and calcium levels were measured using flow cytometry.

Results: Lidocaine protected differentiated N2a cells against cadmium-induced toxicity, and also attenuated cadmium toxicity-induced changes in mitochondrial membrane potential (MMP), reactive oxygen species (ROS) and calcium $\left(\mathrm{Ca}^{2+}\right)$ levels. Furthermore, Bax/Bcl-2 ratio, which was disrupted by cadmium, and cadmium-induced apoptosis, were reversed by lidocaine.

Conclusion: Lidocaine protects differentiated N2a cells against cadmium-induced toxicity by reversing apoptosis. Thus, lidocaine is a potential neuroprotective agent.
\end{abstract}

Keywords: Lidocaine, Anesthesia, Neuroprotection, Cadmium toxicity

\begin{abstract}
This is an Open Access article that uses a fund-ing model which does not charge readers or their institutions for access and distributed under the terms of the Creative Commons Attribution License (http://creativecommons.org/licenses/by/4.0) and the Budapest Open Access Initiative (http://www.budapestopenaccessinitiative.org/read), which permit unrestricted use, distribution, and reproduction in any medium, provided the original work is properly credited.

Tropical Journal of Pharmaceutical Research is indexed by Science Citation Index (SciSearch), Scopus, International Pharmaceutical Abstract, Chemical Abstracts, Embase, Index Copernicus, EBSCO, African Index Medicus, JournalSeek, Journal Citation Reports/Science Edition, Directory of Open Access Journals (DOAJ), African Journal Online, Bioline International, Open-J-Gate and Pharmacy Abstracts
\end{abstract}

\section{INTRODUCTION}

The indispensable role of anesthetics in conferring neuroprotection has been greatly emphasized during post-operative procedures [1]. Neuroprotection can be achieved by limiting inflammatory damage from microglia and delaying cell death in neurons $[2,3]$. Inflammatory damage evoked during operative procedures causes the release of pro-inflammatory cytokines (TNF- $\alpha$, IL- 6 and IL-1 $\beta$ ) from microglia. These inflammatory cytokines act on neurons in their vicinity and direct their death. The inflammatory damage also causes the release of ROS, thereby generating oxidative stress during which various inflammatory pathways (e.g. NF-kB and p38) are switched on in tremendously activated microglia $[4,5]$. These inflammatory events are detrimental to healthy neurons.

Various mechanisms can impart protection to neurons by inhibiting their cell death. Skewing of $\mathrm{Bax} / \mathrm{Bcl}-2$ ratio, and reduction of the levels of Caspase-3 during neuronal death can provide immediate protection to the neurons [6]. The intervention of anesthetics in delaying the toxicity to neurons due to serious insults enhances their therapeutic window. Ischemia-reperfusion is considered the most common source of injury during post-operative procedures in the 
hippocampal and cortical neurons, thereby requiring the protective role of anesthetics $[7,8]$.

Anesthetics in preclinical and clinical use alter the voltage gated channels in neurons, thereby tinkering with the flux of different ions. These voltage gated channels influence the levels of $\mathrm{Na}^{+}$and $\mathrm{K}^{+}$resulting in the generation of membrane potential that translates into nerve impulse [9]. Anesthetics impede the generation of nerve impulse by either inhibiting the movement of ions or obstructing the function of ion channels embedded in the cell membrane [10]. The various neuroprotective effects of anesthetics are well documented in the literature. They have been reported to provide protection to ischemic neurons cultured in vitro by maintaining the ATP content generated by mitochondria [11]. Anesthetics have also been used to provide protection to neurons against injury due to lack of oxygen supply [12].

In a clinical trial study, lidocaine has been shown to provide relief against chronic pain in opioiddependent patients [13]. The objective of this study was to investigate the neuroprotective effect of lidocaine against cadmium-induced toxicity.

\section{EXPERIMENTAL}

\section{Chemicals and reagents}

Streptomycin sulphate, DMEM, penicillin G sodium salt, DMSO (dimethyl sulfoxide), sodium pyruvate, HEPES, MTT, rhodamin-123, Flu-3a, 2,7-dichlorodihydrofluorescein diacetate (DCFHDA), RIPA, BSA, phosphate buffered saline, Annexin V/PI, licodaine, and beta actin were purchased from Sigma (St. Louis, MO, USA). Fetal bovine serums (FBS) was obtained from GIBCO (Invitrogen Corporation). Immobilon Western Chemiluminescent HRP substrate and PVDF membrane were purchased from Merck Millipore, while antibodies were products of Cell Signaling Technology (CST).

\section{Cell culture and treatments}

The N2a cells were purchased from ATCC and were grown at $37^{\circ} \mathrm{C}$ in DMEM with glutamine, penicillin, streptomycin, sodium pyruvate, and 10 $\%$ FBS in a humidified atmosphere containing 5 $\% \mathrm{CO}_{2}$. The cells were differentiated in DMEM containing $2 \%$ FCS with $10 \mu \mathrm{M}$ retinoic acid for 6 days, and the culture medium was replaced every two days. Differentiated $\mathrm{N} 2 \mathrm{a}$ cells were pre-treated with lidocaine at doses of 1, 10, 20 and $30 \mu \mathrm{M}$ for $24 \mathrm{~h}$, and then exposed to cadmium for further $24 \mathrm{~h}$.

\section{Cell proliferation and neuroprotection assay}

Thiazolyl blue tetrazolium bromide (MTT) was used to determine cell viability. Differentiated $\mathrm{N} 2 \mathrm{a}$ cells were grown in 96-well plates at a density of $0.20 \times 10^{5}$ cells per well for $24 \mathrm{~h}$. The cells were pre-treated with lidocaine at various concentrations for $24 \mathrm{~h}$ followed by cadmium treatment $(30 \mu \mathrm{M})$ for $24 \mathrm{~h}$, and MTT dye (2.5 $\mathrm{mg} / \mathrm{mL}$ ) was added to each well at $37{ }^{\circ} \mathrm{C}$ and allowed to react for $4 \mathrm{~h}$ before termination of the experiment. Finally, the media were aspirated and the resultant formazan crystals were dissolved by adding DMSO. Absorbance was measured at $570 \mathrm{~nm}$ using a synergy MX plate reader.

\section{Measurement of intracellular calcium}

Fluo3-AM dye was used to measure intracellular $\mathrm{Ca}^{2+}$ level in the cytoplasm. The cells were seeded in 6-well plates and pre-treated with different concentrations of lidocaine for $24 \mathrm{~h}$, followed by cadmium treatment $(30 \mu \mathrm{M})$ for $24 \mathrm{~h}$. Then, Fluo3-AM dye $(6 \mu \mathrm{M})$ was added, and after $30 \mathrm{~min}$, the cells were washed three times with PBS to remove unbound dye. Then, the cells were collected and subjected to flow cytometric analysis.

\section{Determination of mitochondrial membrane potential}

Mitochondrial membrane potential was determined with rhodamine-123 in differentiated $\mathrm{N} 2 \mathrm{a}$ cells. The cells were seeded on sterile cover slips in 6-well plates for $24 \mathrm{~h}$ at $37{ }^{\circ} \mathrm{C}$, and then were pre-treated with lidocaine at different concentrations $(1,10,20$ and $30 \mu \mathrm{M})$, followed by cadmium treatment for $24 \mathrm{~h}$. The dye TMRE was added at a concentration of $200 \mathrm{nM} 30 \mathrm{~min}$ before termination of the incubation. The cells were then washed with PBS. Mounting media was used for preparing slides which were sealed with nail polish. Images were taken with confocal microscope (Olympus Fluoview FV-10000). For flow cytometry, the cells were grown in 6-well plates and treated with lidocaine and cadmium as specified earlier. After incubation with Rhodamine 12, the cells were collected, resuspended in PBS and subjected to analysis in a flow cytometer (BD FACS Calibur BD Biosciences, San Jose, California).

\section{Measurement of reactive oxygen species}

Differentiated $\mathrm{N} 2 \mathrm{a}$ cells were seeded in 6-well plates for $24 \mathrm{~h}$ at $37^{\circ} \mathrm{C}$. After $24 \mathrm{~h}$, the cells were separately pre-treated with lidocaine at concentrations of $1,10,20$ and $30 \mu \mathrm{M}$, followed 
by cadmium treatment. Thereafter, DCFHDA (10 $\mu \mathrm{M})$ was added to the cells and allowed to react for 30 min before termination of the experiment. The cells were washed three times with PBS followed by trypsinization, after which they were centrifuged at $400 \mathrm{~g}$ for $5 \mathrm{~min}$. Furthermore, the cells were washed two times with PBS and subjected to analysis in a flow cytometer (BD FACS Calibur BD Biosciences, San Jose, California) to measure the florescence intensity of DCFHDA dye.

\section{Western blot}

Differentiated N2a cells were seeded in $60-\mathrm{mm}$ dishes and were differentiated in $10 \mu \mathrm{M}$ retinoic acid supplemented with $5 \%$ FBS for 4 days. The cells were lysed with RIPA buffer containing $1 \%$ protease inhibitor cocktail, $5 \mathrm{mM}$ EDTA, $1 \mathrm{mM}$ $\mathrm{Na}_{3} \mathrm{VO}_{4}, 1 \mathrm{mM}$ PMSF, $20 \mathrm{mM}$ Tris- $\mathrm{HCl}$ and 150 $\mathrm{mM} \mathrm{NaCl}$ for $45 \mathrm{~min}$ followed by vortexing at 10min intervals.

Lysed samples were centrifuged at $13000 \mathrm{~g}$ for $10 \mathrm{~min}$ at $4{ }^{\circ} \mathrm{C}$, and the supernatants were used for protein estimation with the Bradford protein assay kit as per the manufacturer's protocol. For western blotting, $70 \mu \mathrm{g}$ protein was loaded into each well of SDS PAGE and were run for $3 \mathrm{~h}$ at $100 \mathrm{~V}$. The gels were transferred unto PVDF membrane for $2 \mathrm{~h}$ at $100 \mathrm{~V}$.

The membrane was blocked with skimmed milk at room temperature for $1 \mathrm{~h}$. Primary antibodies were added overnight to the membrane at $4{ }^{\circ} \mathrm{C}$, followed by washing thrice with TBST (each for 5 $\mathrm{min})$. Then, the membrane was incubated with secondary antibody at room temperature for $1 \mathrm{~h}$. The membrane was washed three times with TBST (5 $\min$ each), and ECL chemiluminescence kit was used to detect membrane-bound antibodies. The protein bands were analysed with X-ray film.

\section{Annexin V/PI staining}

After plating of N2a cells into 6-well plates, they were pre-treated with lidocaine at doses of 1,10 , 20 and $30 \mu \mathrm{M}$, followed by cadmium treatment for $24 \mathrm{~h}$. After $24 \mathrm{~h}$, the cells were collected, washed three times with PBS and were resuspended in binding buffer. Annexin $\mathrm{V}$ was added for $20 \mathrm{~min}$ in the dark and PI was added 5 min before termination of the experiment as per manufacturer's protocol. The apoptosis-positive cells were detected and analysed using FACS BD CALIBUR flow cytometer, with 10,000 events captured per sample.

\section{Statistical analysis}

Data are shown as mean $\pm S D(n=3)$. One-way analysis of variance (ANOVA) and Tukey's multiple-comparison tests were used for statistical analysis. All statistical analyses were done with SPSS program version 12.0, Origin 8.1 version software (SPSS, Inc Chicago, IL, USA. Values of $p<0.005, p<0.01$ or $p<0.05$ were considered statistically significant, as appropriate.

\section{RESULTS}

\section{Lidocaine protected Neuro2a cells against cadmium-induced cell death}

Fig. 1

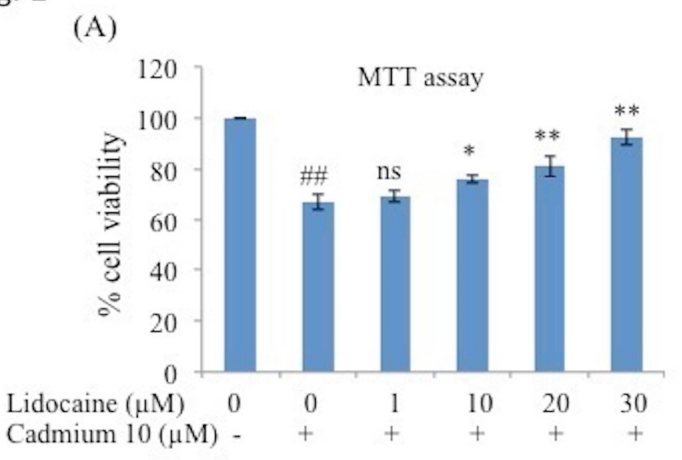

(B)

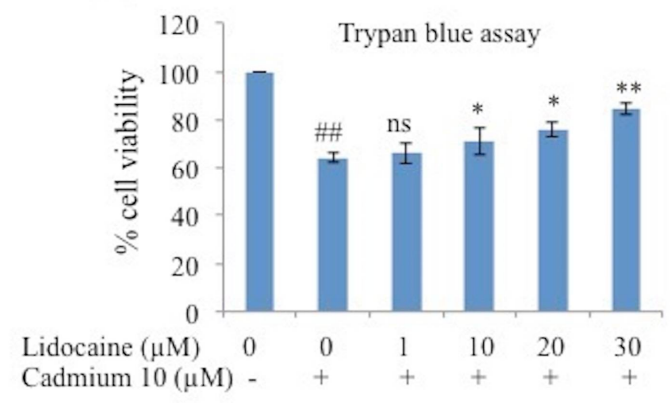

Figure 1: Effect of lidocaine on cadmium toxicity. (A) Cells were pre-treated with lidocaine at various concentrations followed by cadmium exposure, and percentage cell viability was determined using MTT assay. (B) Percentage cell viability determined with Trypan blue assay. Data are shown as mean of three independent experiments. Numbers show significance with respect to untreated, while asterisks indicate significance with respect to cadmium treatment; ${ }^{\# \#} p<$ $0.01,{ }^{*} p<0.05,{ }^{* *} p<0.01$

Different concentrations of lidocaine $(1,10,20$ and $30 \mu \mathrm{M}$ ) were used to pre-treat differentiated $\mathrm{N} 2 \mathrm{a}$ cells prior to exposure to cadmium $(10 \mu \mathrm{M})$ for $24 \mathrm{~h}$. Lidocaine significantly attenuated cadmium toxicity-induced cell death, with $30 \mu \mathrm{M}$ lidocaine producing the highest neuroprotective effects in Trypan blue and MTT assays ( $82 \pm 2 \%$ 
and $92 \pm 3 \%$, respectively) (Figures $1 \mathrm{~A} \& 1 \mathrm{~B}$ ). Attenuation of cell death by various concentrations of lidocaine as determined in Trypan blue and MTT assays were $69 \pm 2$ and 66 $\pm 4 \%$ for $1 \mu \mathrm{M}, 76 \pm 1$ and $71.2 \pm 5 \%$ for $10 \mu \mathrm{M}$, $81 \pm 4$ and $76 \pm 3 \%$ for $20 \mu \mathrm{M}$, and $92 \pm 3$ and $84 \pm 2 \%$ for $30 \mu \mathrm{M}$ respectively. Moreover, there was no significant change in cell viability with increasing concentrations of lidocaine beyond 30 $\mu \mathrm{M}$ (data not shown). Therefore, these results clearly indicate that lidocaine protected N2a cells against cadmium toxicity.

\section{Cadmium-altered Bax and $\mathrm{Bcl}-2$ ratio was normalized by lidocaine}

Cadmium increased the expression of Bax in differentiated $\mathrm{N} 2 \mathrm{a}$ cells, but the increase was attenuated by pre-treatment with lidocaine at different concentrations (Figure 2 A). However, the expression of $\mathrm{Bcl}-2$ was significantly decreased in cadmium-treated differentiated N2a cells, but $\mathrm{Bcl}-2$ was upregulated in lidocaine pretreated cells. The Bax/Bcl2 ratios at lidocaine doses of 10,20 and $30 \mu \mathrm{M}$ were $38 \pm 5,36 \pm 2$ and $24 \pm 3 \%$, respectively (Figure 2 B). Together, these results show that lidocaine appreciably maintained the ratio of $\mathrm{Bax}: \mathrm{Bcl} 2$ in differentiated N2a cells.
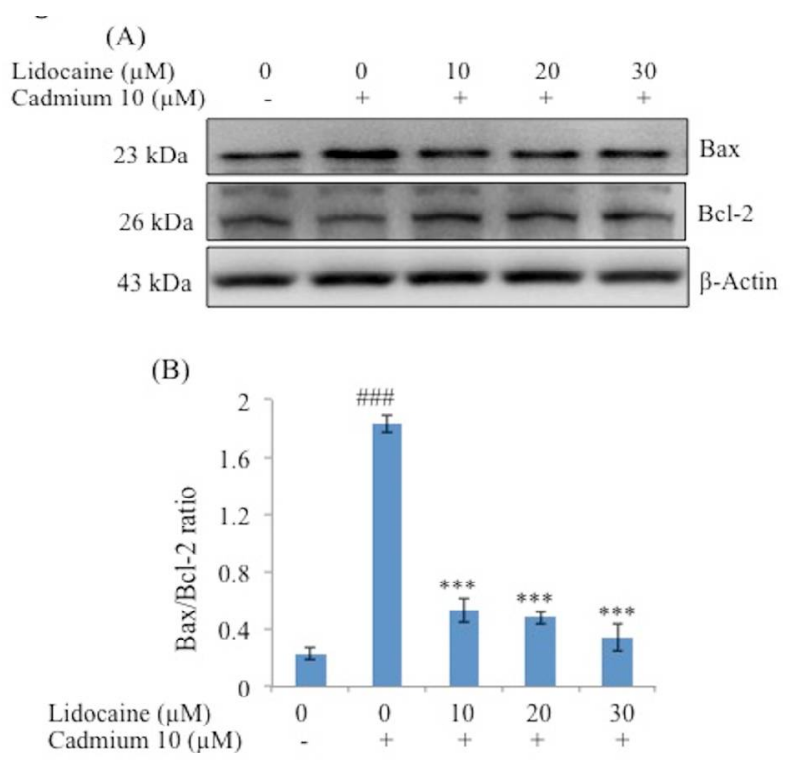

Figure 2: Effect of lidocaine on $\mathrm{Bax}$ and $\mathrm{Bcl}-2$ expressions in cadmium-induced toxicity. (A) Determination of protein expression levels (Bax/Bcl2) using western blot. (B) Graph of Bax:Bcl-2 ratio depicted with densitometry, with $\beta$-actin loading control. Numbers indicate statistical significance relative to untreated control, while asterisks indicate significance when compared with cadmium treatment; \#\# $p<0.001,{ }^{* * *} p<0.001$

\section{Cadmium-induced increases in ROS in N2a cells were attenuated by lidocaine}

Cadmium treatment increased the generation of ROS in N2a cells, as revealed by flow cytometer and confocal microscopy. Cadmium-induced ROS generation was $42 \%$, relative to untreated control (3\%), but it was markedly attenuated to 6 , 8,14 and $20 \%$ in cells treated with lidocaine, as seen in flow cytometry results (Figure $3 \mathrm{~A}$ ). These results were further validated with fluorescence microscopy in which cadmiuminduced ROS (83 $\pm 3 \%)$ was significantly reduced by lidocaine to $72 \pm 2 \%$ at $10 \mu \mathrm{M}, 68 \pm$ $1 \%$ at $20 \mu \mathrm{M}$, and $62 \pm 5 \%$ at $30 \mu \mathrm{M}$, as determined by fluorescence microscopy (Figure $3 \mathrm{~B})$ and relative florescence measurements (Figure 3C).

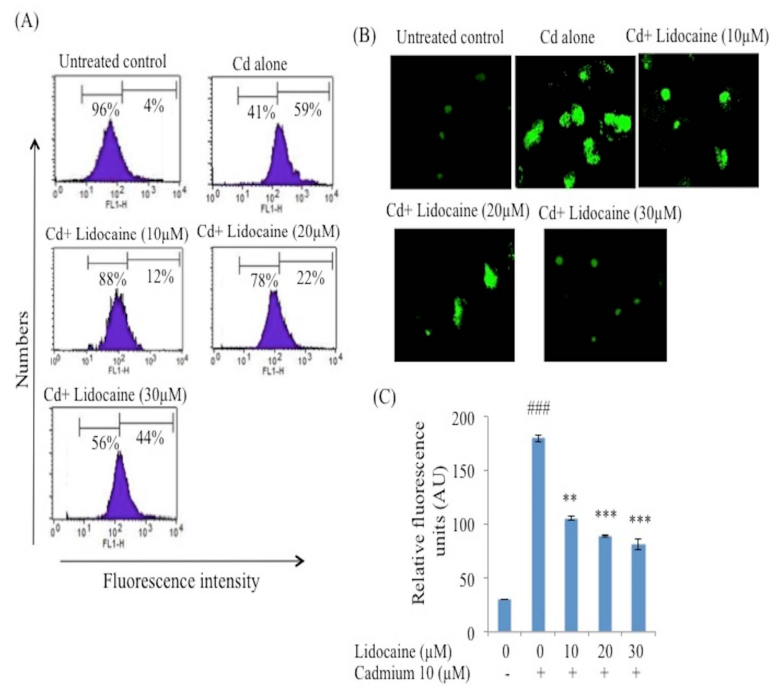

Figure 3: Effect of lidocaine on cadmium-induced generation of ROS. (A) Attenuation of ROS generated by cadmium in N2a cells, as quantified using flow cytometry. (B) Live cell imaging of lidocaine-induced reduction of ROS generation (C) Histogram showing fluorescence intensity of N2a cells. Data are presented as mean of three independent experiments. Number sign shows significance with respect to untreated cells, while asterisks indicate significance with respect to cadmium treatment; \#\#\#p<0.001, ${ }^{* *} p<0.01,{ }^{* * *} p<$ 0.001

\section{Lidocaine attenuated increases in intra- cellular calcium level in N2a cells induced by cadmium}

Cadmium significantly increased intracellular calcium levels in N2a cells, resulting in apoptosis. The cells treated with cadmium had elevated calcium (89 $\pm 3 \%$ ), but this was attenuated to $76 \pm 4 \%, 51 \pm 1 \%$ and $29 \pm 5 \%$ at lidocaine concentrations of 10,20 and $30 \mu \mathrm{M}$, 
respectively in differentiated $\mathrm{N} 2 \mathrm{a}$ cells, as determined by flow cytometry (Figure 4).

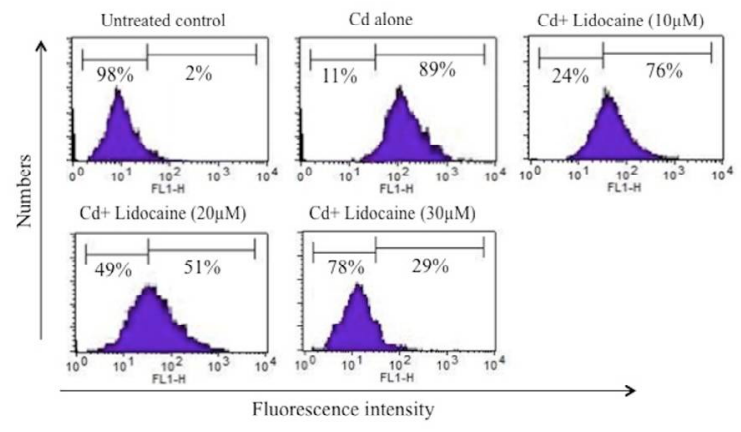

Figure 4: Effect of lidocaine on cadmium-induced changes in intracellular calcium in N2a cells. Cadmium-induced increase in intracellular calcium level was attenuated by lidocaine at doses of 10,20 and $30 \mu \mathrm{M}$, as measured using intensity of FLU-3A dye through flow cytometry

\section{Mitochondrial membrane potential was increased by lidocaine in N2a cells}

Mitochondrial membrane potential plays an important role in cell viability. Any defects in mitochondrial membrane potential leads to apoptosis. Cadmium-induced mitochondrial membrane potential loss $(81 \%)$ in differentiated $\mathrm{N} 2 \mathrm{a}$ cells was reversed by lidocaine in a concentration-dependent manner to 13, 24 and $37 \%$, as shown by flow cytometric assays (Figure $5 \mathrm{~A}$ ). These results were further validated using confocal microscopy in which there was significant increase in mitochondrial membrane potential, when compared with cadmium-treated $\mathrm{N} 2 \mathrm{a}$ cells, as determined by fluorescence microscopy (Figure 5 B) and relative fluorescence measurements (Figure $5 \mathrm{C}$ ).

\section{Lidocaine abrogated apoptosis induced by cadmium}

Cadmium-induced apoptosis in differentiated $\mathrm{N} 2$ a cells was reversed by lidocaine at different concentrations. There was significant increase in cadmium-induced apoptotic population in differentiated N2a cells (60\%), but the increases were markedly reduced by lidocaine at doses of 10,20 and $30 \mu \mathrm{M}$, to 11,22 and $34 \%$, respectively, in a concentration dependent manner (Figure 6). These results were obtained with Annexin V/PI staining through flow cytometry.

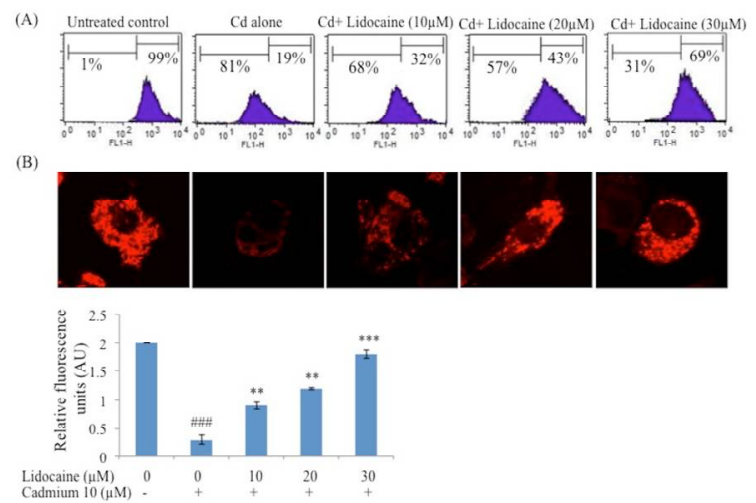

Figure 5: Attenuation of cadmium-induced loss of mitochondrial membrane potential by lidocaine. (A) Mitochondrial membrane potential was determined by flow cytometry. Cadmium decreased mitochondrial membrane potential, but this effect was mitigated by lidocaine. (B) Effect of lidocaine on mitochondrial membrane potential, as determined via confocal microscopy. (C) Histogram showing relative fluorescence intensity (RI) in N2a cells. Data indicate mean of three independent experiments. Numbers show significance with respect to untreated. Asterisks indicate significance with respect to cadmium treatment; \#\#\#p<0.001, ${ }^{\star \star} p<0.01,{ }^{\star \star *} p<0.001$

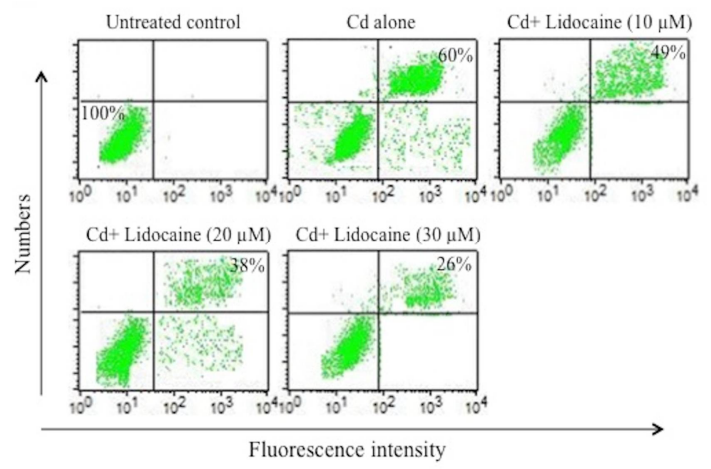

Figure 6: Effect of lidocaine on apoptosis. Cadmiuminduced apoptosis was reversed by lidocaine at doses of 10,20 and $30 \mu \mathrm{M}$

\section{DISCUSSION}

One of the most common medical procedures used to treat various diseases is surgery $[14,15]$. Before performing any medical procedure on the patient, sedatives and anesthesia are administered to reduce pain [16,17]. Anesthesia is medically defined as any agent used for the generation of temporary unconsciousness and loss of awareness. Since all medical surgeries are extremely painful, it is important that pain is reduced so that surgeries can be easily performed [18].

Anesthesia could be general or local, depending on the medical procedure to be performed e.g. local anesthesia is used for toothache because it 
blocks the nerve impulse transmission from CNS to the tooth (affected/target organ). During more serious surgeries where temporary blocking of CNS is required, general anesthesia is given, for example, during excision of tumour mass from a cancer patient [19]. One of such effective anesthetic agents is lidocaine. Due to its easy dosing pattern and stable cardiovascular graph, lidocaine is generally preferred to other drugs. $[20,21]$. Moreover, it confers protection to myocardial cells, and it has minimal suppression of ventilation and decrease in liberation of histamines [22,23]. Although its mode of action has already been discovered, it is not yet clear how lidocaine exerts its cytotoxic effects.

In this study, it was shown that lidocaine protected differentiated $\mathrm{N} 2 a$ cells against cadmium-induced toxicity in concentrationdependent manner. Bax/Bcl2 ratio, which was distorted by cadmium in differentiated N2a cells, was maintained by lidocaine. The cadmiuminduced elevations in calcium and ROS levels, and loss of mitochondrial membrane potential, were dose-dependently reversed by lidocaine. Furthermore, cadmium-induced apoptosis was reversed by lidocaine. These findings are of great importance especially in brain cells wherein these anesthetic drugs which are used to protect the patients may enhance the effect of the treatment. However, further studies need to be conducted in vitro and in vivo to ascertain the clinical significance of lidocaine in this regard.

\section{CONCLUSION}

The findings of this study show that lidocaine protects differentiated N2a cells against cadmium toxicity. It reduces calcium level and reactive oxygen species, increases mitochondrial membrane potential, decreases $\mathrm{Bax} / \mathrm{Bcl} 2$ ratio and suppresses apoptosis. Interestingly, lidocaine blocks cadmium-induced apoptotic cell death. Thus, it exerts protective effects against cadmium-induced damage in Neuro2A cells.

\section{DECLARATIONS}

\section{Conflict of interest}

No conflict of interest is associated with this work.

\section{Contribution of authors}

We declare that this work was done by the authors named in this article and all liabilities pertaining to claims relating to the content of this article will be borne by the authors. Peng Chen and Wenyu Zhang: Wrote the paper, performed, participated and designing most of the experiments, Xuefeng $\mathrm{Li}$ contributes in various experiments. Longyun $\mathrm{Li}$ designed and conceived the experiments and oversaw all aspects of the study. All the authors have read the manuscript and approved for publication.

\section{Open Access}

This is an Open Access article that uses a funding model which does not charge readers or their institutions for access and distributed under the terms of the Creative Commons Attribution License (http://creativecommons.org/licenses/by/ 4.0) and the Budapest Open Access Initiative (http://www.budapestopenaccessinitiative.org/rea d), which permit unrestricted use, distribution, and reproduction in any medium, provided the original work is properly credited.

\section{REFERENCES}

1. Bilotta F, Caramia $R$, Paoloni FP, Favaro $R$, Araimo $F$, Pinto G, Rosa G. Early postoperative cognitive recovery after remifentanil-propofol or sufentanil-propofol anaesthesia for supratentorial craniotomy: a randomized trial. Eur J Anaesthesiol. 2007; 24: 122-127.

2. Perry VH, Nicoll JA, Holmes C. Microglia in neurodegenerative disease. Nat Rev Neurol. 2010; 6(4): 193.

3. Kim CC, Nakamura MC, Hsieh CL. Brain trauma elicits non-canonical macrophage activation states. $J$ Neuroinflammation. 2016; 13: 117.

4. Biber K, Owens $T$, Boddeke $E$. What is microglia neurotoxicity (Not). Glia. 2014; 62: 841-854.

5. Hirata Y, Yamamoto H, Atta MS, Mahmoud S, Oh-hashi $K$, Kiuchi $K$. Chloroquine inhibits glutamate induced death of a neuronal cell line by reducing reactive oxygen species through sigma 1 receptor. J Neurochem. 2011; 119: 839-847.

6. Ma S, Liu H, Jiao H, Wang L, Chen L, Liang J, Zhao M, Zhang $X$. Neuroprotective effect of ginkgolide $K$ on glutamate-induced cytotoxicity in PC 12 cells via inhibition of ROS generation and $\mathrm{Ca}+$ influx. Neurotoxicology. 2012; 33: 59-69.

7. Bilotta F, Gelb AW, Stazi E, Titi L, Paoloni FP, Rosa G. Pharmacological perioperative brain neuroprotection: a qualitative review of randomized clinical trials. $\mathrm{Br} J$ Anaesth. 2013; 110: 113-120.

8. Bilotta F, Doronzio A, Stazi E, Titi L, Fodale V, Di Nino G, Rosa G. Postoperative cognitive dysfunction: toward the Alzheimer's disease pathomechanism hypothesis. $J$ Alzheimers Dis. 2010; 22: 1-9.

9. Brau ME, Vogel W, Hempelmann G. Fundamental properties of local anesthetics: half-maximal blocking concentrations for tonic block of $\mathrm{Na}^{+}$and $\mathrm{K}^{+}$channels in peripheral nerve. Anesth Analg. 1998; 87: 885-889. 
10. Cousins MJ, Bridenbaugh PO, Carr DB, Horlocker TT, editors. Cousins and Bridenbaugh's neural blockade in clinical anesthesia and pain medicine. Lippincott Williams \& Wilkins; 2009. 566 p.

11. Butterworth J, Hammon JW. Lidocaine for neuroprotection: more evidence of efficacy. Anesth Analg. 2002; 95: 1131-1133.

12. Niiyama S, Tanaka E, Tsuji S, Murai $Y$, Satani $M$, Sakamoto $H$, Takahashi K, Kuroiwa M, Yamada $A$, Noguchi M, Higashi H. Neuroprotective mechanisms of lidocaine against in vitro ischemic insult of the rat hippocampal CA1 pyramidal neurons. Neurosci Res. 2005; 53: 271-278.

13. Leng T, Gao X, Dilger JP, Lin J. Neuroprotective effect of lidocaine: is there clinical potential. Int $J$ Physiol Pathophysiol Pharmacol. 2016; 8: 9.

14. Cheng AL, Kang YK, Chen Z, Tsao CJ, Qin S, Kim JS, Luo R, Feng J, Ye S, Yang TS, XU J. Efficacy and safety of sorafenib in patients in the Asia-Pacific region with advanced hepatocellular carcinoma: a phase III randomised, double-blind, placebo-controlled trial. Lancet Oncol. 2009; 10: 25-34.

15. Fidler IJ. The pathogenesis of cancer metastasis: the 'seed and soil' hypothesis revisited. Nat Rev Cancer. 2003; 3: 453.

16. Innes G, Murphy M, Nijssen-Jordan C, Ducharme J, Drummond A. Procedural sedation and analgesia in the emergency department. Canadian Consensus Guidelines. J Emerg Med. 1999; 17: 145-156.

17. Krauss B, Green SM. Sedation and analgesia for procedures in children. New England $N$ Engl J Med. 2000; 342: 938-945.

18. Ghoneim MM, Block Rl, Haffarnan M, Mathews MJ. Awareness during anesthesia: risk factors, causes and sequelae: a review of reported cases in the literature. Anesth Analg. 2009; 108: 527-535.

19. Soma LR. Anesthetic and analgesic considerations in the experimental animal. Ann N Y Acad Sci. 1983; 406: 3247.

20. Barbi E, Gerarduzzi T, Marchetti F, Neri E, Verucci E, Bruno I, Martelossi S, Zanazzo G, Sarti A, Ventura A. Deep sedation with propofol by non-anesthesiologists: a prospective pediatric experience. Arch Pediatr Adolesc Med. 2003; 157: 1097-1103.

21. Hull CJ. Phaeochromocytoma: diagnosis, preoperative preparation and anaesthetic management. $\mathrm{Br} J$ Anaesth. 1986; 58: 1453-1468.

22. Southerland JH, Brown LR. Conscious intravenous sedation in dentistry: a review of current therapy. Dent Clin North Am. 2016; 60: 309-346.

23. Lars G. Svensson: Aortic dissection and aortic aneurysm surgery: Clinical observations, experimental investigations, and statistical analyses part I. Curr Probl Surg. 1992; 817-911. 